\title{
Effect of Naphthalene Acetic Acid (NAA) on Growth and Yield of Rosemary (Rosemarinus officinalis L.) under Salinity Stress.
}

\author{
Hanan M. Abou El-ghit \\ Department of Botany and Microbiology, Faculty of Science, \\ University of Helwan, Cairo, Egypt.
}

\begin{abstract}
7 HE PRESENT study is an attempt to investigate the effect of saline soil at the levels of $0,1000,3000$ and $5000 \mathrm{mg} / \mathrm{l}$ and foliar application of Naphthalene acetic acid (NAA) at $0.0,25,75,125,200$ and $300 \mathrm{ppm}$ on vegetative growth, chemical composition and oil yield production of Rosemary plant. The results indicated that increasing salinity levels decreased all measured growth parameters, chemical composition and oil production. However, foliar application of NAA reduced the harmful effects of salinity and improved the growth by increasing the concentration of NAA up to $200 \mathrm{ppm}$ then decreased at higher NAA concentration (300 ppm).
\end{abstract}

Keywords: Rosemary, Salt stress, Synthetic auxins, Naphthalene Acetic Acid (NAA), Oil analysis.

Rosemary, Rosemarinus officinalis L. is a flowering perennial herb with evergreen needle like highly aromatic and fragrant leaves, native to the Mediterranean region, Europe and the Near East (Zargari, 1990).

Rosemary is well cultivated in Egypt and available throughout the year. It is one of the important medicinal and aromatic plants used externally as parasiticide, cicatrisant for muscular pain and rheumatism, dermatitis, dandruff and exzema. It promotes hair growth. It is used internally for asthma, bronchitis headache, renal flatulence (Valnet, 1973 and Lawless, 1992) and it is used for its volatile oil which is useful as anti-inflammatory activities, anticancer, muscle contraction, reducing carcinogens and tumors.

Soil salinity is a major abiotic stress in plant agriculture worldwide. Egypt is one of the countries that suffer from sever salinity problems and there are wide saline areas, which cause harmful effects on plant growth and its production. The harmful effects of salinity on medicinal plants and aromatic plants were mentioned by Francois et al. (1990), Hamad (1996) and Pathan et al. (2000) on guar, El-Shafey et al. (1991) and Zidan and Al-Zahrani (1994) on sweet basil, Ali (1996) on hyoscyamus, Dawh et al. (1998) on Taget erecta, Khalil (1999) 
on Nigella sativaon, Said Al-Ahl (1999) on basil, Ahmed et al. (2001) on damisissa and Attia ( 2003) on cluster bean. Paradia (2002) reported that growth inhibition was a common response to salinity. Shaddad and Heikal (1982) found that salt stress inhibited growth parameters in maize, cotton, pea and wheat.

Salinity induced damage in DNA, Lipids, carbohydrates and proteins and caused aberrant cell signaling (Arora et al., 2002) resulting in delayed germination, poor stand establishment (Almansourit et al., 2001), high seedling motility, stunted growth and lower yields (Allakhverdievet et al., 2006;

Plant growth regulators are synthesized indigenously by plants, however, several studies demonstrated that plants can respond to exogenous application of these chemicals. Exogenous application of plant growth regulators affects the endogenous hormonal pattern of the plant, either by supplementation of suboptimal levels or by interaction with their synthesis, translocation, activation or inactivation of existing hormone levels (Arshad and Frankenberger, 1993).

Application of growth regulators has good management effect on growth and yield of field crops. Hormones regulate physiological process and synthetic growth regulators may enhance growth and development of field crops thereby increased total dry mass (Das and Das, 1996; Abd-el-Fattah, 1997; Dakua, 2002; Islam, 2007 and Cho et al., 2008).

Auxins are phytohormones play an essential role in coordination of many growth and behavioral processes in the plant life cycle. They are major coordinating signals in plant development. Also auxin have bioregulator effects on physiological and biochemical processes in plants such as ion uptake, cell elongation, cell division, cell differentiation, sink/source regulation, enzymatic activities, protein synthesis and photosynthetic activity as well as increase the antioxidant capacity of plants (Blokhina et al., 2003 and El-Tayeb, 2005). Auxins also induce sugar and mineral accumulation at the site of application, induce the formation and organization of xylem and phloem. When the plant is injured, the endogenious auxin can induce the cell differentiation and regeneration of the vascular tissues (Chaparzadeh et al., 2004).

Naphthalene Acetic Acid (NAA) belongs to synthetic forms of auxins which play a key role in cell elongation, cell division, vascular tissue, differentiation, root initiation, apical dominance, leaf senescence, leaf and fruit abscission, fruit setting and flowering (Davies, 1987). Growth and yield parameters of rice are significantly promoted in response to various auxin levels (Zahir, et al., 1998). Naphthalene acetic acid had a significant effect on plant height, number of fruiting branches, volume of boll and yield in cotton (Abro et al., 2004). Naphthalene acetic acid $20 \mathrm{ppm}$ showed better performance in enhancing the straw and grain yields of wheat cultivars (Alam, et al., 2002). Naphthalene acetic acid has been used for the enhancement of growth and yield of cereals (Lilani, et al., 1991). It produces significant effects in promoting development of pointed ends for the root system, resulting in more, straighter and thicker

Egypt. J. Bot., 56, No. 1 (2016) 
roots. NAA can increase fruit setting ratio, prevent fruit dropping, promote flower sex ratio. Foliar application of NAA has also found to increase plant height, number of leaves per plant, fruit size with consequent enhancement in seed yield in different crops (Lee, 1990). Favourable influence of auxins such as NAA has been reported on invertase content of sugarcane (Sacher and Glasziou, 1962; Sacher et al., 1963). Govindan et al., (2000) indicated that soybean plants sprayed with NAA at $40 \mathrm{ppm}$ after 35 days of sowing had significant increases in growth characters, yield and its attributes including number of pods and seeds, plant, seeds/pod and 100 seed weight. Senthil et al., (2003) investigated the effects of NAA at $40 \mathrm{ppm}$ and IAA at $100 \mathrm{ppm}$ supplied as foliar spray at 35 and 60 days after sowing on some biochemical and physiological aspects including total chlorophyll and soluble protein of soybean plant. They reported that all treatments increased the biochemical parameters of soybean and IAA treatment had the highest effects on the plant Naphthalene acetic acid is a synthetic growth regulator has proved its potentiality that in appropriate concentration NAA affects the growth and yield of a number of plants viz. tomato (Chhonkerar and Singh, 1959), bitter gourd (Jahan and Fattah, 1991) and cowpea (Ullah et al., 2007).

\section{Material and Methods}

The pot experiment was carried out on 2013/2014 to examine the physiological responses of Rosmarinus officinalis L. to salinity and foliar spray of naphthalene acetic acid (NAA) treatments. Also their combined treatments were investigated. Trials were conducted in triplicate using a randomized complete block design. Terminal cuttings of rosemary plant $(15-20 \mathrm{~cm}$ long) were transplanted in $40 \mathrm{~cm}$ diameter plastic pots filled with $15 \mathrm{~kg}$ dry clay. Salinity stress was applied a month after transplantation. Four saline water samples were used as $0.0,1000,3000$ and $5000 \mathrm{mg} / \mathrm{l}(\mathrm{NaCl})$. Pot irrigation was carried out three times a week. Weeds were removed mechanically and no pesticides were applied during the growing season. Plants were thinned after rooting, three plants / pot were left. Two cuttings $(10 \mathrm{~cm})$ above the soil surface were taken from rosemary plant; the first one was seven months after transplanting, while the second was carried out after three months from the first cut.

A plot design with three replicates was used; the main plot was the different concentrations of Naphthalene acetic acid (0.0, 25, 75, 125, 200 and 300 ppm), while the sub-plots were the different concentrations of salinity $(0.0,1000,3000$ and $5000 \mathrm{mg} / \mathrm{l})$. Twice foliar spray of NAA was done. The first spray was applied on two months after transplanting, while the second spray was applied one week later after the first one. Spraying with NAA was repeated again after two months from the first cut. Control plants were irrigated and sprayed with $\mathrm{H} 2 \mathrm{O}$. Urea was applied twice at the rate of $1 \mathrm{~g}$ per pot. At full blooming stage, the aerial parts were harvested by cutting $10 \mathrm{~cm}$ above the soil surface and plant 
growth parameter were recorded i.e. plant height $(\mathrm{cm})$, number of branches per plant as well as fresh and dry weights (g). Chemical analyses were done including photosynthetic pigments, carbohydrates and oil contents. Chlorophyll $\mathrm{a}, \mathrm{b}$ and carotenoids contents in the fresh leaves $(\mathrm{mg} / \mathrm{g} . \mathrm{F} . \mathrm{W})$ were determined in samples according to Saric et al. (1967). Total and soluble carbohydrates contents were determined according to the method described by Dubois et al. (1956). Insoluble carbohydrates were estimated by subtraction of soluble carbohydrates from total carbohydrates. Representative fresh samples were taken from each treatment for determination of essential oil percentage and essential oil yield/plant using British Pharmacopoeia (1963) method. All obtained data were statistically analyzed by the method of Snedecore and Cochran (1981).

\section{Results}

Effect of salinity and NAA treatments on vegetative growth (plant height, number of branches, fresh and dry weights) of rosemary

Table 1.a, 1.b, 1.c and 1-d clarify that, plant height, number of branches/plant, fresh and dry weights of rosemary plant significantly increased by low level of salinity $1000 \mathrm{mg} / \mathrm{l}$, while declined with increasing salinity concentration from 3000 $\mathrm{mg} / \mathrm{l}$ to $5000 \mathrm{mg} / \mathrm{l}$ in both seasons. NAA application showed a significant positive effect on the mentioned growth parameters up to $200 \mathrm{ppm}$, whereas higher NAA concentration $(300 \mathrm{ppm})$ showed a negative effect on vegetative growth. The highest lengths, the maximum branch numbers, the highest fresh and dry weights were detected at salinity concentration of $1000 \mathrm{mg} / \mathrm{l}$ and $200 \mathrm{ppm}$ NAA.

TABLE 1.a. Effect of salinity and NAA treatments on plant height (cm) of Rosmarinus officinalis $\mathbf{L}$. plant.

\begin{tabular}{|c|c|c|c|c|c|c|}
\hline \multirow{2}{*}{$\begin{array}{c}\text { Salinity } \\
(\mathbf{m g} / \mathbf{l})\end{array}$} & \multicolumn{7}{|c|}{ NAA (ppm) } \\
\cline { 2 - 7 } & $\mathbf{0 . 0}$ & $\mathbf{2 5}$ & $\mathbf{7 5}$ & $\mathbf{1 2 5}$ & $\mathbf{2 0 0}$ & $\mathbf{3 0 0}$ \\
\hline 0.0 & 33.2 & 36.7 & 38.1 & 41.6 & 45.8 & 23.1 \\
\hline 1000 & 37.2 & 39.5 & 42.4 & 45.5 & 53.3 & 28.4 \\
\hline 3000 & 24.9 & 30 & 35.5 & 39.2 & 42.4 & 20.0 \\
\hline 5000 & 15.4 & 19.2 & 24.8 & 29.7 & 38.7 & 10.2 \\
\hline L.S.D.at 5\% & 1.01 & 0.62 & 0.63 & 1.63 & 1.07 & 1.03 \\
\hline L.S.D at 1\% & 1.98 & 1.11 & 0.83 & 1.91 & 1.75 & 1.71 \\
\hline
\end{tabular}

TABLE 1.b. Effect of salinity and NAA treatments on number of branches/plant of Rosmarinus officinalis $\mathbf{L}$. plant .

\begin{tabular}{|c|c|c|c|c|c|c|}
\hline \multirow{2}{*}{$\begin{array}{c}\text { Salinity } \\
(\mathbf{m g} / \mathbf{l})\end{array}$} & \multicolumn{7}{|c|}{ NAA (ppm) } \\
\cline { 2 - 7 } & $\mathbf{0 . 0}$ & $\mathbf{2 5}$ & $\mathbf{7 5}$ & $\mathbf{1 2 5}$ & $\mathbf{2 0 0}$ & $\mathbf{3 0 0}$ \\
\hline 0.0 & 8.7 & 12.7 & 14.2 & 16.4 & 18.8 & 7.2 \\
\hline 1000 & 10.2 & 13.8 & 15.5 & 18.9 & 20.8 & 8.5 \\
\hline 3000 & 7.1 & 10.7 & 12.4 & 14.3 & 16.2 & 4.2 \\
\hline 5000 & 5.7 & 8.1 & 10.0 & 11.9 & 13.8 & 2.7 \\
\hline L.S.D at 5\% & 0.84 & 1.0 & 0.96 & 1.11 & 1.02 & 0.31 \\
\hline L.S.D at 1\% & 0.98 & 1.7 & 1.22 & 1.76 & 1.42 & 0.92 \\
\hline
\end{tabular}

Egypt. J. Bot., 56, No. 1 (2016) 
TABLE 1.c. Effect of salinity and NAA treatments on fresh weight (g) of Rosmarinus officinalis L. plant.

\begin{tabular}{|c|c|c|c|c|c|c|}
\hline \multirow{2}{*}{$\begin{array}{c}\text { Salinity } \\
(\mathbf{m g} / \mathbf{l})\end{array}$} & \multicolumn{7}{|c|}{ NAA $(\mathbf{p p m})$} \\
\cline { 2 - 7 } & $\mathbf{0 . 0}$ & $\mathbf{2 5}$ & $\mathbf{7 5}$ & $\mathbf{1 2 5}$ & $\mathbf{2 0 0}$ & $\mathbf{3 0 0}$ \\
\hline 0.0 & 150.3 & 159 & 164.5 & 172.6 & 182.7 & 120.4 \\
\hline 1000 & 156.6 & 161.4 & 168.2 & 177.3 & 195.3 & 124.1 \\
\hline 3000 & 140.3 & 144.4 & 148.7 & 153.9 & 160.3 & 111.2 \\
\hline 5000 & 84.2 & 95.7 & 124.4 & 130.7 & 136.4 & 60.4 \\
\hline L.S.D at 5\% & 0.41 & 0.83 & 0.99 & 0.88 & 1.05 & 1.10 \\
\hline L.S.D at 1\% & 1.2 & 0.98 & 1.80 & 1.76 & 1.41 & 1.83 \\
\hline
\end{tabular}

TABLE 1.d. Effect of salinity and NAA treatments on dry weight (g) of Rosmarinus officinalis $L$. plant.

\begin{tabular}{|c|c|c|c|c|c|c|}
\hline \multirow{2}{*}{$\begin{array}{c}\text { Salinity } \\
(\mathbf{m g} / \mathbf{l})\end{array}$} & \multicolumn{7}{|c|}{ NAA $(\mathbf{p p m})$} \\
\cline { 2 - 7 } & $\mathbf{0 . 0}$ & $\mathbf{2 5}$ & $\mathbf{7 5}$ & $\mathbf{1 2 5}$ & $\mathbf{2 0 0}$ & $\mathbf{3 0 0}$ \\
\hline 0.0 & 26.4 & 31.2 & 35.1 & 42.3 & 46.1 & 18.3 \\
\hline 1000 & 32.2 & 35.7 & 39.1 & 44.1 & 49.4 & 21.4 \\
\hline 3000 & 20.1 & 24.1 & 26.3 & 28.2 & 34.2 & 16.9 \\
\hline 5000 & 12.4 & 19.8 & 21.1 & 24.1 & 29.9 & 9.9 \\
\hline L.S.D at 5\% & 0.88 & 0.98 & 0.83 & 0.79 & 0.89 & 0.52 \\
\hline L.S.D at $1 \%$ & 1.10 & 1.32 & 1.72 & 1.42 & 1.22 & 0.83 \\
\hline
\end{tabular}

Effect of salinity and NAA treatments on photosynthetic pigment content

Data recorded in Table 2. a, b and c shows that low salinity concentration $(1000 \mathrm{mg} / \mathrm{l})$ increased chlorophyll a, b and carotenoids $(\mathrm{mg} / \mathrm{g}$. Fresh weight of leaves), whereas higher salinity concentrations reduced their contents. NAA treatments up to $200 \mathrm{ppm}$ reduced the harmful effect of salinity, but higher NAA treatment $(300 \mathrm{ppm})$ had an adverse effect on photosynthetic pigments concentration.

Chlorophylls and carotenoids concentrations were markedly improved in rosemary leaves as a result of foliar spray of low concentrations of NAA. The lower level of salinity $1000 \mathrm{mg} / \mathrm{l}$ combined with $200 \mathrm{ppm}$ NAA produced the highest pigments concentration, whereas the highest NAA concentration $(300 \mathrm{ppm})$ reduced significantly pigments concentration compared with control. 
TABLE 2.a. Effect of salinity and NAA treatments on chlorophyll "a" content (mg/g fresh weight) in leaves of Rosmarinus officinalis L. plant .

\begin{tabular}{|c|c|c|c|c|c|c|}
\hline \multirow{2}{*}{$\begin{array}{c}\text { Salinity } \\
\mathbf{m g} / \mathbf{l}\end{array}$} & \multicolumn{7}{|c|}{ NAA (ppm) } \\
\cline { 2 - 7 } & $\mathbf{0 . 0}$ & $\mathbf{2 5}$ & $\mathbf{7 5}$ & $\mathbf{1 2 5}$ & $\mathbf{2 0 0}$ & $\mathbf{3 0 0}$ \\
\hline 0.0 & 1.17 & 2.06 & 3.06 & 4.60 & 7.68 & 0.72 \\
\hline 1000 & 2.12 & 3.01 & 4.13 & 5.96 & 9.11 & 1.21 \\
\hline 3000 & 1.01 & 1.93 & 2.62 & 3.71 & 6.55 & 0.51 \\
\hline 5000 & 0.61 & 0.71 & 0.94 & 1.27 & 2.92 & 0.35 \\
\hline L.S.D at 5\% & 0.25 & .17 & 0.52 & 0.22 & 0.52 & 0.49 \\
\hline L.S.D at 1\% & 0.44 & 0.29 & 0.74 & 0.37 & 0.72 & 0.61 \\
\hline
\end{tabular}

TABLE 2.b. Effect of salinity and NAA treatments on chlorophyll "b" content (mg/g fresh weight) in leaves of Rosmarinus officinalis L. plant.

\begin{tabular}{|c|c|c|c|c|c|c|}
\hline \multirow{2}{*}{$\begin{array}{c}\text { Salinity } \\
\mathbf{m g} / \mathbf{l}\end{array}$} & \multicolumn{7}{|c|}{ NAA (ppm) } \\
\cline { 2 - 7 } & $\mathbf{0 . 0}$ & $\mathbf{2 5}$ & $\mathbf{7 5}$ & $\mathbf{1 2 5}$ & $\mathbf{2 0 0}$ & $\mathbf{3 0 0}$ \\
\hline 0.0 & 0.39 & 0.46 & 0.53 & 0.79 & 1.97 & 0.22 \\
\hline 1000 & 0.71 & 0.80 & 1.01 & 1.98 & 3.76 & 0.37 \\
\hline 3000 & 0.27 & 0.36 & 0.45 & 0.62 & 0.94 & 0.19 \\
\hline 5000 & 0.17 & 0.24 & 0.38 & 0.43 & 0.24 & 0.11 \\
\hline L.S.D.at 5\% & 0.044 & 0.071 & 0.013 & 0.032 & 0.022 & 0.031 \\
\hline L.S.D.at 1\% & 0.082 & 0.090 & 0.051 & 0.052 & 0.076 & 0.092 \\
\hline
\end{tabular}

TABLE 2.c. Effect of salinity and NAA treatments on carotenoids contents (mg/g fresh weight) in leaves of Rosmarinus officinalis L. plant.

\begin{tabular}{|c|c|c|c|c|c|c|}
\hline \multirow{2}{*}{$\begin{array}{c}\text { Salinity } \\
\mathbf{m g} / \mathbf{l}\end{array}$} & \multicolumn{6}{|c|}{ NAA (ppm) } \\
\cline { 2 - 7 } & $\mathbf{0 . 0}$ & $\mathbf{2 5}$ & $\mathbf{7 5}$ & $\mathbf{1 2 5}$ & $\mathbf{2 0 0}$ & $\mathbf{3 0 0}$ \\
\hline 0.0 & 0.130 & 0.182 & 0.191 & 0.242 & 0.403 & 0.075 \\
\hline 1000 & 0.155 & 0.191 & 0.261 & 0.390 & 0.621 & 0.081 \\
\hline 3000 & 0.046 & 0.063 & 0.088 & 0.130 & 0.255 & 0.031 \\
\hline 5000 & 0.034 & 0.048 & 0.090 & 0.098 & 0.119 & 0.019 \\
\hline L.S.D.at 5\% & 0.009 & 0.004 & 0.005 & 0.003 & 0.008 & 0.004 \\
\hline L.S.D.at 1\% & 0.015 & 0.008 & 0.009 & 0.004 & 0.003 & 0.090 \\
\hline
\end{tabular}

Effect of salinity and NAA treatments on content of total, soluble and insoluble carbohydrates:

The increases of the photosynthetic pigments in the treated rosemary leaves were concomitant with a gradual increase in total, soluble and insoluble carbohydrates as shown in Table 3.a, 3.b and 3c. 
TABLE 3.a. Effect of salinity and NAA treatments on total carbohydrates content (mg/g fresh weight) in leaves of Rosmarinus officinalis $\mathbf{L}$. plant.

\begin{tabular}{|c|c|c|c|c|c|c|}
\hline \multirow{2}{*}{$\begin{array}{c}\text { Salinity } \\
\mathrm{mg} / \mathrm{l}\end{array}$} & \multicolumn{7}{|c|}{ NAA (ppm) } \\
\cline { 2 - 7 } & 0.0 & 25 & 75 & 125 & 200 & 300 \\
\hline 0.0 & 313.9 & 371.5 & 442.3 & 500.1 & 612.4 & 218.4 \\
\hline 1000 & 435.8 & 504.4 & 592.6 & 638.2 & 701.3 & 294.1 \\
\hline 3000 & 251.5 & 270.5 & 339.8 & 391.6 & 458.5 & 158.7 \\
\hline 5000 & 140.1 & 200.4 & 291.6 & 320.3 & 432.9 & 71.4 \\
\hline L.S.D.at 5\% & 3.20 & 3.83 & 4.78 & 2.93 & 4.66 & 3.65 \\
\hline L.S.D.at 1\% & 4.57 & 5.14 & 5.43 & 4.21 & 6.21 & 4.06 \\
\hline
\end{tabular}

TABLE 3.b. Effect of salinity and NAA treatments on soluble carbohydrates content (mg/g fresh weight) in leaves of Rosmarinus officinalis $\mathbf{L}$. plant.

\begin{tabular}{|c|c|c|c|c|c|c|}
\hline \multirow{2}{*}{$\begin{array}{c}\text { Salinity } \\
\text { mg/l }\end{array}$} & \multicolumn{7}{|c|}{ NAA (ppm) } \\
\cline { 2 - 7 } & $\mathbf{0 . 0}$ & $\mathbf{2 5}$ & $\mathbf{7 5}$ & $\mathbf{1 2 5}$ & $\mathbf{2 0 0}$ & $\mathbf{3 0 0}$ \\
\hline 0.0 & 79.2 & 88.4 & 103.7 & 113.5 & 128.7 & 61.3 \\
\hline 1000 & 99.3 & 110.4 & 121.7 & 131.4 & 152.1 & 72.6 \\
\hline 3000 & 59.4 & 63.6 & 70.6 & 80.5 & 88.44 & 52.8 \\
\hline 5000 & 43.9 & 50.4 & 55.7 & 59.4 & 71.3 & 32.6 \\
\hline L.S.D.at 5\% & 1.04 & 3.73 & 3.12 & 2.60 & 3.56 & 3.19 \\
\hline L.S.D.at 1\% & 2.51 & 4.97 & 5.84 & 3.63 & 4.90 & 5.22 \\
\hline
\end{tabular}

TABLE 3.c. Effect of salinity and NAA treatments on insoluble carbohydrates content (mg/g fresh weight) in leaves of Rosmarinus officinalis $\mathrm{L}$. plant.

\begin{tabular}{|c|c|c|c|c|c|c|}
\hline \multicolumn{6}{|c|}{ NAA (ppm) } & \multirow{2}{*}{$\begin{array}{c}\text { Salinity } \\
\text { mg/l }\end{array}$} \\
\hline 300 & 200 & 125 & 75 & 25 & 0.0 & \\
\hline 157.1 & 483.7 & 386.6 & 338.6 & 283.1 & 234.5 & 0.0 \\
\hline 221.5 & 549.2 & 506.8 & 470.9 & 394 & 336.5 & 1000 \\
\hline 105.9 & 370.1 & 311.2 & 269.2 & 206.9 & 192.1 & 3000 \\
\hline 38.8 & 361.6 & 260.9 & 235.9 & 150 & 96.2 & 5000 \\
\hline 4.04 & 3.91 & 4.61 & 4.07 & 4.55 & 2.11 & L.S.D.at $5 \%$ \\
\hline 6.11 & 5.11 & 5.32 & 5.11 & 5.29 & 3.74 & L.S.D.at $1 \%$ \\
\hline
\end{tabular}

Effect of salinity and NAA treatments on oil percentage and oil yield of rosemary plant:

The results in Table $4 \mathrm{a}-\mathrm{b}$ indicated that there was a significant increase in oil percentage and oil yield due to the lowest concentration of salinity $(1000 \mathrm{mg} / \mathrm{l})$, whereas higher salinity levels drastically affected oil percentage and yield. 
Concerning NAA treatments, the data indicated that there was a significant increase in oil percentage and oil yield by increasing the NAA concentration up to $200 \mathrm{ppm}$, whereas $300 \mathrm{ppm}$ NAA considerably decreased both parameters. Moreover, the combination between the highest salinity concentration (5000 $\mathrm{mg} / \mathrm{l})$ and the highest NAA treatment (300 ppm) caused the least oil percentage and oil yield and the maximum levels of both parameters were obtained by using $1000 \mathrm{mg} / \mathrm{l}$ salinity and $200 \mathrm{ppm}$ NAA.

TABLE 4.a. Effect of salinity and NAA treatments on volatile oil percentage of Rosmarinus officinalis L. plant.

\begin{tabular}{|c|c|c|c|c|c|c|}
\hline \multicolumn{6}{|c|}{ NAA (ppm) } & \multirow{2}{*}{$\begin{array}{c}\text { Salinity } \\
\text { mg/l }\end{array}$} \\
\hline 300 & 200 & 125 & 75 & 25 & 0.0 & \\
\hline 0.17 & 0.92 & 0.66 & 0.54 & 0.43 & 0.32 & 0.0 \\
\hline 0.23 & 1.85 & 0.88 & 0.71 & 0.52 & 0.43 & 1000 \\
\hline 0.11 & 0.76 & 0.61 & 0.44 & 0.35 & 0.25 & 3000 \\
\hline 0.077 & 0.58 & 0.46 & 0.34 & 0.25 & 0.13 & 5000 \\
\hline 0.009 & 0.031 & 0.023 & 0.021 & 0.011 & 0.009 & L.S.D.at 5\% \\
\hline 0.011 & 0.044 & 0.057 & 0.033 & 0.017 & 0.011 & L.S.D.at $1 \%$ \\
\hline
\end{tabular}

TABLE 4.b. Effect of salinity and NAA treatments on volatile oil yield (ml/plant) of Rosmarinus officinalis L. plant.

\begin{tabular}{|c|c|c|c|c|c|c|}
\hline \multicolumn{6}{|c|}{ NAA (ppm) } & \multirow{2}{*}{$\begin{array}{c}\text { Salinity } \\
\text { mg/l }\end{array}$} \\
\hline 300 & 200 & 125 & 75 & 25 & 0.0 & \\
\hline 0.241 & 0.952 & 0.762 & 0.653 & 0.532 & 0.402 & $\mathbf{0 . 0}$ \\
\hline 0.303 & 1.711 & 0.871 & 0.721 & 0.666 & 0.533 & 1000 \\
\hline 0.123 & 0.823 & 0.610 & 0.501 & 0.332 & 0.211 & 3000 \\
\hline 0.083 & 0.605 & 0.541 & 0.454 & 0.334 & 0.145 & 5000 \\
\hline 0.010 & 0.012 & 0.074 & 0.009 & 0.053 & 0.009 & L.S.D.at $5 \%$ \\
\hline 0.014 & 0.019 & 0.098 & 0.012 & 0.088 & 0.019 & L.S.D.at $1 \%$ \\
\hline
\end{tabular}

\section{Discussion}

The stimulative effect of lower level of salinity stress shown in our data may be attributed to the production of great amount of secondary plant products such as phenols, terpenes, $\mathrm{N}$ as well as essential oils by plants under salt stress (Mosaleeyanonet et al., 2005). Also plants commonly react to salt stress by accumulation of solutes in cells, or osmotic adjustment, which has resulted in improved environmental stress tolerance (Mathews et al., 1984). Solutes involved in osmotic adjustment are typically sugars, amino acids, inorganic ions and organic acids (Morgan, 1984). Glycine betaine (GB) and proline are two major organic osmolytes that accumulate in a variety of plant species in response to environmental stresses such as drought, salinity, extreme temperatures, UV radiation and heavy metals. Although their actual roles in

Egypt. J. Bot., 56, No. 1 (2016) 
plant osmotolerance remain controversial, both compounds are thought to have positive effects on enzyme and membrane integrity along with adaptive roles in mediating osmotic adjustment in plants grown under stress conditions.

The harmful effect of excess soluble salts in the soil may be attributed to osmotic stress, specific ion toxicity and ionic imbalances and consequently plant death or yield loses in crop species and medicinal plants (Munns, 2003 and Le Rudulich, 2005).

According to the results shown in our work, NAA has both stimulatory and inhibitory effect on the different measured growth and yield parameters, this depends on its concentration. NAA at low concentrations showed a progressive increase in plant height, number of branches/plant, fresh and dry weights up to $200 \mathrm{ppm}$ at which the highest length of plants, maximum number of branches and the highest fresh and dry weights of plants were recorded. Whereas 300 ppm NAA led to reduction in these growth parameters. These results are corroborated with those of El-Tayeb (2005) on barley, Gunes et al. (2005) on maize and Dawood et al. (2012) on sunflower.

Moreover, our results are in agreement with Akter (2010) who reported an increase in number of cob per plant due to NAA treatment in maize as well as Dasgupta (1975) who obtained reduced pod length with higher concentrations of NAA on groundnut. The results also are in conformity with the findings of Singh et al. (1972) on pea and Ullah et al.(2007) on cowpea who reported that 1000-grain weight decreased due to higher concentration of NAA application. Moreover, the achieved increase in peppermint yield per plant with low concentrations of NAA might be attributed to increased assimilative area and as a result more photosynthesis throughout the growth period (Balba and Tallat 2007).

The ameliorative effect of NAA could be attributed to its role in coordination of development at all levels in plants from the cellular level to organs and ultimately the whole plant, while the adversely effect of higher concentration of NAA may be attributed to stimulation of ethylene production that can inhibit elongation growth, causing leaf abscission, and even kill the plant (Szepesi et al., 2005).

The enhancing effects of NAA on photosynthetic capacity could be attributed to its stimulatory effects on tryptophan activity and pigment contents (Khodary, 2004) as well as increased CO2 assimilation, photosynthetic rate and increased mineral uptake by the plant (Szepesi et al., 2005). In addition, Arfan et al. (2007) pointed that application of auxin improved the photosynthetic capacity and retained pigment content in wheat cultivars under salt stress therefore inhibiting their senescence. 
The increase in pigment level by NAA presented in our data could be attributed to the promotion in its synthesis and/or retardation of pigment degradation as recommended by Sharma et al. (1995) who found that excised leaves of Tropaeolum majus treated with auxin retained more chlorophyll $(60 \%$ higher at $10^{-3} \mathrm{M}$ ) compared to control. Moreover, the potent effects of particularly growth regulator might be ascribed to the reduction in chlorophyll loss due to its ability to increase the antioxidant capacity of the plants or inducing the synthesis of stabilizing substances.

The stimulatory effect of NAA spray on the total carbohydrate content shown in our results is in agreement with those obtained by Balbaa, and Talaat (2007) who reported that, application of NAA increased the total, soluble and insoluble carbohydrate percentage in peppermint leaves. Also Dawood et al. (2012) reported a significant increase in total, soluble and insoluble carbohydrate content in leaves of sunflower as a result of NAA application, thus NAA application maintained the carbohydrate pool in the chloroplasts at a high level.

The increment in oil content as a result of NAA treatment might be due to the achieved increase in vegetative growth, metabolism and nutrient uptake. Similar results were reported by Çag et al. (2009). In addition, Noreen and Ashraf (2010) mentioned that NAA caused marked increases in sunflower achene oil content.

Thus, our data may lead to conclude that NAA could be a potent growth regulator to improve growth and yield of Rosemary plant cultivated under salinity stress.

\section{References}

Abd-El-Fattah, M.A. (1997) Effect of phosphorus, boron, GA3 and their interaction on growth, flowering, pod setting, abscission and yield of broad bean. Alexandria J. Agril. Res., 42: 311-332.

Abro, G.H., Syed, T.S., Umer, M.I. and Zhang, J. (2004) Effect of application of a growth regulator and micronutrients on insect pest infestation and yield components of cotton. J. Entomol., 1(1): 12-16.

Ahmed, A., Shadia, K., Ali, A.F. and Khater, M.R. (2001) Effect of salinity treatments and active dry yeast on growth and active ingredient of Ambraosis maritime L. Proc. Fifth Arabian Horticulture Conference, Ismilia, Egypt, March 25-28: 217-224.

Akter, R. (2010) Effect of naphthalene acetic acid (NAA) on growth, physiological and biochemical responses and yield attributes of maize (Zea mays L. var. Pacific 283). M. S. Thesis. Department of Botany,University of Dhaka, Dhaka.

Alam, S.M., Shereen, A. and Khan, M. (2002) Growth response of wheat cultivars to naphthalene acetic acid (NAA) and ethrel. Pak. J. Bot., 34(2): 135-137.

Egypt. J. Bot., 56, No. 1 (2016) 
Allakahverdievet, S. I., Sakamoto, A., Nishiyama, Y., Inaba, M., and Murata, N. (2006) Ionic and osmotic effets of $\mathrm{NaCl}$ induced inactivation of photosystem I and II in Synechocccus sp. Plant Physiology., 123:1047-1056.

Ali, M.A.M. (1996) Physiological studies on Egyptian henbane in El- Arish Region Ph.D Thesis, Fac.Environmental Agri. Sci., Suez Canal University.Arish.

Almansourit, M., Kinet, J.M. and Lutts, S. (2001) Effect of salt and osmotic stresses on germination in durum wheat (Triticum aestivum). Plant Soil, 231: 243-254.

Arfan, M.H, Athar, R. and Ashraf, M. (2007) Does exogenous application of IAA modulate growth and photosynthetic capacity in two differently adapted spring wheat cultivars under salt stress. J. Plant Phys., 6 (4) : 685-694.

Arora, A., Sairam, R. K., and Srivastva, G. C. (2002) Oxidative stress and antioxidative systems in plants. Curr. Sci., 82: 1227- 1238.

Arshad, M. and Frankenberger, J. (1993) Microbial production of plant growth regulators : 307- 347. In: "Soil Microbial Echol". F.B. Metting Jr. (Ed), Marcel Dekker Inc., N. Y. Int. J. Agri Crop Sci. Vol., 7 (14) : 1378-1380, 2014

Attia, D.M. (2003) Physiological studies on guar plants in sandy soil. M.Sc. Thesis, Fac.Agric., Suez Canal University.

Balbaa, L.K. and Talaat, I.M .(2007) Physiological response of rosemary plants to different growth regulators. Egypt. J. Appl. Sci., 22: (11B) 375-385

Blokhina, E., Virolainen, K.V. and Fagerstedt. (2003) Antioxidants, oxidative damage and oxygen deprivations stress. Ann. Bot., 91: 179-194 (A review)

British Pharmacopoeia (1963) "Determination of Volatile in Drugs". The Pharmaceutical Press. London

Çag, S., Gul, C.C., Sarsag, M. and Goren-Saglam, N. (2009) Effect of some growth regulators on pigment, protein content and peroxidase activity in excised sunflower cotyledons. Pak. J. Bot., 41 (5): 2297-2303

Chaparzadeh, N. M. L. D., Amico, R. A., Khavari- Najad, R. and Navarizzo, F. (2004) Antioxadative responses of Calendula officinalis under salinity conditions and auxin treatment. Plant Physiology and Biochemistry, 42: 695-701.

Chhonkerar, V.S. and Singh, S.N. (1959) Effect of naphthalene acetic acid on growth, quality and yield of tomato. Ind. J. Hort., 16(4): 236-242.

Cho, M.H., HK, No. and Prinyawiwatkul, W. (2008). Chitosan treatments affect growth and selected quality of sunflower sprouts. J. Food Sci., 73: 570-577. 
Dakua, M.F. (2002) Effect of CI-IAA, TNZ-303 and GABA on growth, yield and yield contributing characters of lentil. M. S. Thesis, Dept. Crop Bot., Bangladesh Agric. Univ., Mymensingh.

Das, B.C. and Das, T.K. (1996) Studies on the response of GA3, NAA and Etherl on the vegetative growth and yield of pumpkin. Orisssa J. Hort., 24: 74-78.

Dasgupta, D.K. (1975) Effect of NAA on crop plants in sierra leoue. I. Groundnut Expl. Agril., II: 209-213.

Davies P.J. (1987) "Plant Hormone and Their Role in Plant Growth and Development". Martinus Nijhoff Publ. Dordrecht, Netherlands.

Dawh, A.K., Omer, E.A. and Rashed, E.M. (1998) Yield of leaves and oil of Tagets erecta as affected by salinity and growth regulators. Egypt. J. Horti., 25(2): 145-165.

Dawood, M.G, Sadak, M.S. and Hozayen, M. (2012) Physiological role of naphthalene acetic acid in improving performance, yield and some biochemical aspects of sunflower plant grown under newly reclaimed sandy soil . Aust. J. Bas. Appl. Sci., 6 (4) $82-89$.

Dubois, M., Gilles, K.A., Hamilton,J.K., Roberts, P.A and Smith, F. (1956) Phenol sulphuric acid method for carbohydrate determination. Ann. Chem., 28: 350-359

El-Shafey, S., Awad, A. Meawad, A. and El- Shaer, M. (1991) II- leaf pigments and chemical constituents of sweet basil plants, Zagazig J. Agric. Res. 18 (6): 2234-2247.

El-Tayeb, M.A. (2005) Response of barley grains to the interactive effects of salinity and auxin . Plant Growth Regul., 45 : 215-224.

Francois, L.E., Donovan, T.J. and Maas, E.V. (1990) Salinity effects on emergence, vegetative growth and seed yield of guar, Agronomy Journal, 82 (3): 587-592. US Salinity Laboratory, Riverside, CA 92501, USA Hort. Abst., 61 (6): 49041.

Govindan, K., Thirumurugan, V. and Arulchelvan, S. (2000) Response of soybean to growth regulators. Res. Crops India. 1: 323-325.

Gunes, A., Inal, A., Alpaslan, M. Cicek, N. Guneri, E., Eraslan, F. and Guzelordu,T. (2005) Effects of exogenously applied IAA on the induction of multiple stress tolerance and mineral nutrition in maize (Zea mays L.) Arch. Agron. and Soil Sci., 51 : 687-695

Hamad, E.H.A. (1996) Effect of salinity and some growth regulators on guar plants. M.Sc. Thesis, Fac. Agric., Zagazig University.

Islam, M.M. (2007) Effect of GABA on growth, yield and yield contributing characters of sesame. M. S. Thesis. Dept. Crop Bot., Bangladsh Agric. Univ., Mymensingh.

Jahan, N. and Fattah, Q.A. (1991) Effect of foliar treatments of NAA and IBA on reproductive and yield parameters of bitter gourd (Momordica charantia L.). Dhaka Univ. Stud. Part E. Biol. Sci., 6(1): 69-71. 
Khalil, A.M. M. (1999) Physiological studies on the effect of saline water irrigation and some growth regulators on Nigella sativa plants. Ph. D. Thesis, Fac. Agric., Zagazig Univ.

Khodary, S.E.A.(2004) Effect of different auxins on the growth, photosynthesis and carbohydrate metabolism in salt stressed maize plants. Intern. J. Agric. Biol., 6 (1) : 5-8.

Lawless., Julia (1992) "The Eucyclopedia of essential oils. Element Books Ltd." Longmead, Shaflesbury, Dorest Britain, 226 p.

Lee, HS. (1990) Effect of pre-sowing seed treatment with GA3 and IAA on flowering and yield components of groundnut. Korean J. Crop Sci., 35(1): 1-9.

Lilani, A.T., Joshi, T. and Mishra, R.K. (1991) NAA-mediating growth and macro molecular changes in wheat primary leaf serial section. Indian J. Plant Physiol., 34: 311-318.

Le Rudulier, D. (2005) Osmoregulation in Rhizobia: The key role of compatible solutes. Grain Legume, 42: 18-19.

Mathews, M. A., Van Volkenburgh, E. and Boyer, J. S. (1984) Acclimation of leaf growth to low water potentials in sunflower. Plant, Cell\& Environment., 7:199-206.

Misra, A. N., Sahu, S. Misra, M. M., Singh, P., Das, N. Kar, M. and Sahu, P. (1997) Sodium chloride induced changes in leaf growth, pigment and protein contents in two rice cultivars. Journal of Plant Biology., 39: 257-262.

Morgan, J. M. (1984) Osmoregulation and water stress in higher plant. Annual Review Journal of Plant Physiology, 35: 299-319.

Mosaleeyanonet, K., Zobyed, S. M. A., Afreen, F. and Kozai, T. (2005) Relationships between net photosynthetic rate and secondary metabolite contents in St. Johns wort. Plant Science, 169: 523-531.

Muhammad,Z., and F. Hussain, (2010) Effect of $\mathrm{NaCl}$ salinity on germination and seedling growth of some medicinal plants. Pak. Journal of Botany, 42(2): 889-897.

Munns, R. (2003) Comparative physiology of salt and water stress. Plant, Cell\& Environment, 25: 239-250.

Noreen, S. and Ashraf, M. (2010) Modulation of salt $(\mathrm{Na} \mathrm{Cl})$ induced effects on oil composition and fatty acid profile of sunflower (Helianthus annuus L.) by exogenous application of NAA .J. Sci. Food Agric., 90 (15): 2608-2616

Pathan, A.R.K., Chhipa , B., Lal, R. and Vyas, K.K. (2000) Response of cluster bean to saline and sodic waters under different soils, Annals of Agric. Res., 21 (1): 42-46 (C.F. Hort. Abst. Vol. 70 (9) No.7781).

Paradia, A.A. (2002) $\mathrm{NaCl}$ stress causes changes in photosynthetic pigments, proteins and other metabolic components in the leaves of a true mangrove, Bruguiera parviflora, in hydroponic cultures. Journal of Plant Biology, 45: 28-36. 
Shaddad, M. A. and Heikal, M. M. (1982) Proline induced modification in the response of maize to salinity stress. Bull. Faculty of Science Assuit University, 11 (1): 169-184.

Sacher, J.A. and Glasziou, K.T. (1962) Regulation of invertase levels in sugarcane by an auxin-carbohydrate mediated control system. Biochem. Biophys. Res. Commun., 8: 280-282.

Sacher, J.A., Hatch, M.D. and Glasziou, K.T. (1963) Regulation of invertase synthesis in sugarcane by an auxin- and sugar-mediated control system. Physiologia Plant., 16: 836- 842.

Said, A.L. and Ahl, H.A.H. (1999) Physiological studies on the effect of soil salinity on sweet basil plants. M. Sc. Thesis, Fac. Agric., Cairo Univ.

Saric, M., Kastrori, R, Cupina, T. and Gerie, I. (1967) "Chlorophyll Determination". Univ. Unoven Sadu Parktikum is Fiziologize Bilijaka, Beogard, Hauncan, Anjiga, 215. P.

Senthil, A., Pathmanaban, G. and Srinivasan, P.S. (2003) Effect bioregulators on some physiological and biochemical parameters of soybean (Glycine max L.). Legume Res. India, 26: 54-56.

Sharma, S.S, Charan, B. and Rai, V.K. (1995) Influence of auxin on senescence of detached tropaeolum majus leaves in relation to stomatal movements. J. Plant Phys., 146 : 751-753.

Singh, T., Sinhgbad, B.V. and Panwar, B.S. (1972) Effect of pre-sowing treatments with phytohormones on the yield of pea (Pisum sativum). Ind. J. Agril. Res., 6(4): 279-284.

Snedecore, G.W. and Cochran, W.G. (1981) "Statistical Methods". $7^{\text {th }}$ ed., Iowa State Univ. Press, Ames, Iowa, USA, 305 P.

Szepesi, A., Cciszar, J. Bajkan, S. Gemes, K., Horvath, F., Erdei, L., Deer, A.K., Simon, M.L and Tar, I. (2005) Role of auxin pre-treatment on the acclimation of tomato plants to salt and osmotic stress. Acta Biol. Szeged., 49:123-125.

Ullah, M.J., Fatttah, Q.A. and Hossain, F. (2007) Response of growth, yield attributes and yield to the application of KNap and NAA in cowpea (Vigna unguiculata (L.) Walp.). Bangladesh J. Bot., 36(2): 127-132.

Valnet, J. (1973) "Aromatherpia". Maloine Paris, France 406 p.

Zahir, Z.A., Rahmanm, A., Asghar, N. and Arshad, M. (1998) Effect of an auxin precursor L-tryptophan on growth and yield of rice. Pak. J. Biol. Sci., 1(4): 354-356.

Zargari, A. (1990) Medicinal plants. Tehran University., 4:71-76.

Zidan, M.A. and Zahrani, H.S. (1994) Effect of $\mathrm{NaCl}$ on the seedling germination and some metabolic changes in sweet basil (Ocimum basilicum L.) Pakistan J. Sci., 37 (12): 541-543. 


$$
\begin{aligned}
& \text { تأثير الملوحة والرش الورقى بنفثالين حمض الخليك على النمو } \\
& \text { والتركيب الكيميائى وانتاج الزيت لنبات حصا البان. } \\
& \text { قنان محمد أبو الغيطي }
\end{aligned}
$$

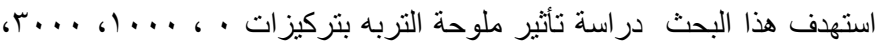

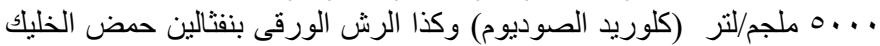

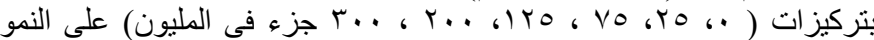
الخضرى و التركيب الكيميائى و انتاج الزيت لنبات حصا البان.

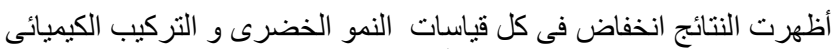

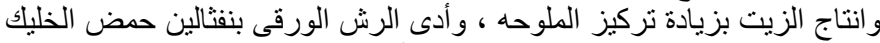

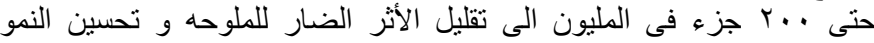

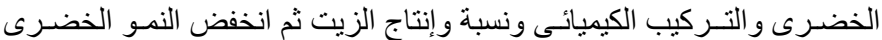

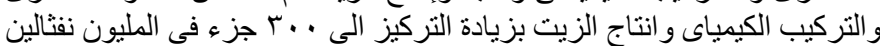

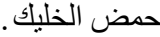

